\title{
Yaşam Memnuniyeti Üzerinde Etkili Olan Faktörlerin Araştırılması: Kayseri İli Örneği
}

\author{
DOI: 10.26466/opus.791217
}

*

\author{
Hakan Eygü* - Arife Kılınç ** \\ * Doç. Dr., Atatürk Üniversitesi, İ.I.B.F, Ekonometri Bölümü, Erzurum, Türkiye \\ E-Posta: hakaneygu@atauni.edu.tr \\ ORCID: 0000-0002-4104-2368 \\ ** Doktora Öğrencisi, Atatürk Üniversitesi, İ.İ.B.F., Ekonometri Bölümü, Erzurum, Türkiye \\ E-Posta: arifeklnc38@gmail.com \\ ORCID: $\underline{0000-0002-6541-340 \mathrm{X}}$
}

\section{Öz}

Bu çalışmanın temel amacl, Kayseri ilinde yaşayan bireylerin yaşam memnuniyetini etkileyen çeşitli faktörlerin etkisini araştırmaktır. Bu amaçla, çalışmada Türkiye İstatistik Kurumu'nun Kayseri ilinde 2786 kişiye uygulamış olduğu 2013-Yaşam Memnuniyeti Anketi verilerinden yararlanılmıştır. Belirlenen bağımsız değişkenlerin bağımlı değişken üzerindeki etkilerinin araştırılmasında ve bu değişkenler arasındaki ilişkinin tespit edilmesi regresyon analizleri önemli yer almaktadır. Bağıml değişken ve model varsayımlarının să̆lanması halinde doğrusal ve logit modeller uygulanabilmektedir. Bu kapsamda elde edilen veriler incelenmiş ve Siral Lojistik Regresyon modelin kullanılmasının uygun olduğu belirlenmiştir. Literatürde yer alan daha önceki çalışmalara bakıldı̆̆ında bireylerin yaşam memnuniyetini etkileyen faktörler arasındaki ilişkiyi il bazında sınırlandırarak istatistiksel olarak özellikle sıralı lojistik regresyon modelleri ile ortaya koyan çok fazla çalışma bulunmamaktadır. Araştırma sonucunda, bağımsız değiş̧kenlerimiz olan sağlık, eğitim, gelir, sosyal hayat, akraba ilişkileri, çalışma durumu, kişisel durum, medeni durum, ulaşım hizmetleri, asayiş hizmetleri ve okul bitirme durumu ile bă̆̆mlı değiş̧kenimiz yaşam memnuniyeti arasında istatistiksel olarak anlaml ilişkiler oldŭ̆u tespit edilmiş ve yorumlanmıştır.

Anahtar Kelimeler: Yaşam Memnuniyeti, Stralı Lojistik Regresyon, Kayseri 


\title{
The Research of Factors That Affects on Life Satisfaction: The Sample of Kayseri Province
}

\begin{abstract}
The main purpose of this study is to research the influence of various factors that affects the life satisfaction of individuals living in Kayseri province. For this purpose, data the 2013-Life Satisfaction Survey, which the applied to 2786 people living in Kayseri province of Turkish Statistical Institute were used in the study. It was determined that it is appropriate to use Ordered Logistic Regression model for the obtained data. Considering the previous studies partaking in the literature, there are not many studies that reveal statistically, especially with ordered logistic regression models, by limiting the relationship between factors that affects the life satisfaction of individuals on a provincial basis. As a result of the research, it was determined that there are statistically significant relationships between our independent variables which are health, education, income, social life, relatives, working status, personal status, marital status, transportation services, public order services and school leaving status with our dependent variable which is life satisfaction.
\end{abstract}

Keywords: Life Satisfaction, Ordered Logistic Regression, Kayseri. 


\section{Giriş}

Günümüzde sosyoloji, psikoloji, felsefe ve edebiyat gibi sosyal bilimler alanlarında araştırılmakta olan yaşam memnuniyeti kavramı son zamanlarda ekonomi ve tıp biliminin de çalışma konularından biri haline gelmiştir (Kartal, Yirci ve Özdemir, 2015). İlk kez 1961 yılında Neugarten tarafından kullanılmış olan yaşam memnuniyeti kavramı, Shin ve Johnson (1978)'a göre, kişinin belirlediği kriterlere göre kendi yaşam kalitesini değerlendirmesidir (Diener, Emmons, Larsen and Griffin, 1985).

Kişinin yaşamından duyduğu memnuniyet ile yaşam kalitesi arasında doğru orantı vardır. Çünkü yüksek yaşam memnuniyeti toplumlarda yaşam kalitesi seviyesinin iyi olduğuna işaret etmektedir. Aynı şekilde düşük yaşam memnuniyeti ise yaşam kalitesi seviyesinde bazı önemli eksikliklerin olduğunu göstermektedir. Dolayısıyla yüksek yaşam memnuniyeti kişilerin ulaşmak istedikleri bir durumdur. Kişinin yaşam memnuniyetini etkilediği düşünülen birçok kriterden söz etmek mümkündür. Başlıca kriterler arasında aile, yaşanılan çevre, sağlık durumu, gelir düzeyi, eğitim düzeyi, cinsiyet, yaş, medeni durum, sosyal ilişkiler, güvenlik, özgürlük ve yaptığı iş sayılabilir (Ahn, Garcia ve Jimeno, 2004). Bu kriterlerin fazlalığı göz önüne alındığında yaşam memnuniyetini farklı kriterler ile sinırlandırarak ya da belli bir alanda daraltarak ölçme yoluna gidenler olmuştur. Ayrıca literatürde yaşam memnuniyetinin farklı değişkenler ile ilişkisinin incelendiği çalışmaların varlı̆̆ından da söz edilebilir. Bu çalışmalardan biri Kangal (2013) tarafından gerçekleştirilmiş olan "Mutluluk Üzerine Kavramsal Bir Değerlendirme Ve Türk Hanehalkı İçin Bazı Sonuçlar" başlıklı araştırmadır. 2004-2010 yıllarına ait verilerin kullanıldığı çalışmada mutluluk kavramını demografik bilgiler (yaş, cinsiyet, eğitim, evlilik gibi) üzerinden hareket ederek açıklamaya çalışmıştır. Servet (2017) ise, 2004 ve 2014 yılları anket verilerini kullanarak, mutluluk düzeyi ile hanehalkı geliri, yaş, cinsiyet, eğitim durumu, sağlık memnuniyeti, refah düzeyi gibi değişkenler arasındaki ilişkiyi sıralı lojistik regresyon kullanarak analiz etmiştir. Ülkemizde yaşam memnuniyeti konusunda gerçekleştirilen en kapsamlı çalışma Türkiye İstatistik Kurumu tarafından yapılmaktadır. TÜIK tarafından Yaşam Memnuniyeti Araştırmasının amacı; bireyin genel mutluluk algısını, toplumsal değerlerini, temel yaşam alanlarındaki genel memnuniyetini ve bu alanlardaki kamu hizmetlerinden memnuniyetini 
ölçmektir. Aynı zamanda bu memnuniyet düzeyinin zaman içindeki değişimini takip etmektir (TUİ, 2015).

Bu çalışmada, Kayseri ilinde yaşayan kişilerin yaşam memnuniyetini etkileyen faktörler, Türkiye İstatistik Kurumunun 2013 yılında yayımlamış olduğu mikro veri seti kullanılarak araştırılmıştır. Sıralı lojistik regresyon analizinin kullanıldığ çok sayıda değişkene yer verilmiştir. Çalışma sonucunda elde edilen bulgular modellenmiş ve yaşam memnuniyetine ilişkin sonuçların değerlendirilmesi yapılmıştır. Bu doğrultuda bireylerin yaşam memnuniyeti konusunun istatistiksel bakış açısıyla ele alınmasının literatüre katkı sağlayacağı düşünülmektedir. Çalışmamızda öncelikle yaşam memnuniyeti kavramı hakkında genel bir değerlendirmeye yer verilmiştir. Ardından yaşam memnuniyeti üzerinde etkili olan faktörler konusunda daha önce yapılan çalışmaların içerik ve sonuçlarına değinilmiştir. Sonraki bölümde ise çalışmanın metodolojisi ve araştırma sonuçlarına ilişkin genel değerlendirmeler ortaya konulmuştur.

\section{Yaşam Memnuniyeti Kavramsal Çerçeve}

Literatürde yaşam memnuniyetinin incelenmesi konusunda birçok çalışma bulunmaktadır. Bu çalışmalarda yaşam memnuniyetini etkileyen farklı değişkenlerin var olduğu görülmektedir. Olena (2005), Ukrayna'da yaşam memnuniyetini belirleyen faktörleri probit ve logit modeller ile incelemiş, özellikle diğer ülkelerdeki çalışmalardan elde edildiği gibi gelirin yaşam memnuniyetindeki etkisinin beklenenden az olup olmadığ 1 konusuna odaklanmıştır. Çalışmasında gelirin Ukrayna'da da büyük bir etkiye sahip olmadığ1 ancak işsizliğin önemli bir negatif etkiye sahip olduğu sonucuna ulaşmıştır. Gürsakal ve Öngen (2008), Türkiye İstatistik Kurumunun 2007 yılında yayımlamış olduğu yaşam memnuniyeti anketi verilerini kullanarak bireylerin yaşam memnuniyetini araştırdıkları çalışmada, yaşam memnuniyetinin hem cinsiyet hem de kır -kent ayrımına göre farklılıklar gösterdiğini ortaya koymuşlardır. Elde edilen bir diğer bulgu ise kamu hizmetlerinden memnuniyet sorularına verilen cevapların kır-kent grup üyeliği ayrımının yapılabilmesi için gerçekleştirdikleri diskriminant analizi sonucunda doğru sınıflandırma yüzdesini \%90 olarak bulmuşlardır. Kahyaoğlu 2008 yılında yaptığı çalışmasında Türkiye İstatistik Kurumu tarafından 6714 kişiye uygulanan 2004 yılına ait hanehalkı yaşam memnuniyeti anket verilerini kullanmıştır. 
Yaşam memnuniyetini etkileyen faktörler sıralı probit model ile belirlenmeye çalışılmıştır. Çalışma bulguları; kadın bireylerin erkeklere göre daha mutlu olduğu, yaşlı bireylerin beklentilerin aksine mutlu oldukları, gelirin, sağlığın ve refah düzeyindeki artışların mutluluk düzeyini artırdığı, kentte yaşamanın ve eğitim düzeyinin artmasının mutluluk üzerinde arttırıc bir etkisinin olduğu şeklinde özetlenebilir. Kapteyn, Smith ve Soest (2009) çalışmalarında, iki ülkede (Hollanda ve Amerika) yaşam memnuniyetini belirleyen faktörleri, internet üzerinden ulaştıkları hanehalkının yanıtlarıyla elde edilen panel verileri kullanarak belirlemeye çalışmışlar ve dört yaşam alanının (iş ve günlük aktiviteler, sosyal bağlar ve aile, sağlık, gelir) yaşam memnuniyetini belirlemede etkili olduğu sonucuna ulaşmışlardır. Çalışmada, Amerikalıların tepkilerinin Hollandalıların tepkilerinden daha aşırı olduğunu (cevapların çok mutlu ya da çok mutsuz olarak değiştiğini) belirlemişleridir. Aynı zamanda her iki ülkede de gelirin yaşam memnuniyetini belirlemede en az etkili faktör olduğu sonucuna ulaşmışlardır. Giray (2011), 2008 yılına ait TÜİK'in Yaşam Memnuniyeti Anketi verilerini kullanarak sosyo-demografik etkenler ile mutluluk algısı arasındaki ilişki yapısını incelemiştir. Doğrusal Olmayan Kanonik Korelasyon analizinin kullanıldığı çalışmada genç, evli ve ev kadınlarının yaşam memnuniyetlerinin orta üst mutluluk seviyesinde, kentte ikamet eden, ortaokul mezunu, çalışan ve 700-900 TL arası gelire sahip olan erkeklerin de yaşam memnuniyetlerinin orta üst mutluluk seviyesinde olduğunu tespit etmiştir. Aynı zamanda kendilerini en çok mutlu eden kişilerin tüm aileleri olduğu sonucuna ulaşmıştır. Akın ve Şentürk (2012) çalışmada 2007 yılına ait Avrupa Yaşam Kalitesi Anketi verileri aracilığıyla elde edilen ikincil verileri kullanmışlardır. Bireylerin sosyo-demografik özelliklerine göre mutluluk düzeylerini elde etmek ve elde edilen sonuçların daha önceki çalışmalarla karşılaştırılması amaçlanmıştır. Yani yıllar itibariyle mutluluk düzeyindeki değişmelerin farklı çalışmalar ile ortaya çıkarılması bu çalışmanın asıl amacıdır. Çalışma ile sosyo-demografik özellikler bakımından mutluluk düzeylerinin yıllara göre değişebileceğini fakat yine de temelde benzer sonuçlar vereceği sonucuna ulaşılmıştır. Aktaş, Özkan ve Oku (2012) Antalya, Isparta ve Burdur (Batı Akdeniz Bölgesi) illerinde yaşayan kişilerin yaşam memnuniyetini etkileyen sosyo-ekonomik faktörleri incelemişlerdir. Logit modelleri kullanarak yaptıkları çalışmada şehir büyüdükçe hanehalkı reisinin memnuniyetinin azaldığı sonucuna ulaşmışlardır. Ayrıca eğitim ve 
gelir düzeyinin yaşam memnuniyetini pozitif yönde etkilediğini tespit etmişlerdir. Bülbül ve Giray (2012), TÜiK'in 2008 yılına ait yaşam memnuniyeti anketi verilerini kullanarak iş ve özel yaşam memnuniyeti arasında bir ilişkinin olup olmadığını ve ilişkinin varlığı halinde bu ilişkinin düzeyinin ne derecede olduğunu araştırmışlardır. Araştırma sonucunda, iş ve özel yaşam memnuniyeti arasındaki ilişkinin \%66 olduğu bulunmuştur. Kutlar, Işık ve Torun (2013), kadınların refah düzeylerini etkileyen faktörleri belirlemeye yönelik yaptıkları çalışmada Türkiye' nin üç farklı şehrini (Adıyaman, Kocaeli ve Isparta) ele almışlardır. Çalışmada 2912 örneklem alınmış ve refahı belirleyen faktörler hem il bazında hem de bütün olarak analiz edilmiştir. Araştırmada sigorta güvencesinin sağlık masraflarını karşılama derecesi, sağlık durumu ve doktora gitme sıklığı gibi göstergelerin kadınların yaşam memnuniyetini pozitif yönde etkilediği sonucuna ulaşılmıştır. Demircan (2015) çalışmasında TÜIKK tarafından 2012 yılında yapılan fert ve hane kapsamlı yaşam memnuniyeti anketi verilerini kullanmıştır. Çalışmada veri madenciliği uygulanarak; veri bütünleştirme, kayıp değerlerin doldurulması, tutarsız ve aşırı uç değerlerin temizlenmesi gibi süreçler sonunda elde edilen veri kümeleri ile sınıflandırma algoritmaları çalıştırılarak veri kümelerini ifade eden sınıflandırma kuralları belirlenmiştir. Sonuç olarak yaşam memnuniyeti araştırması üzerinde ortalamada \%70 doğruluk değerlerine ulaşılmıştır. Korkmaz, Germir, Yücel ve Gürkan (2015), 2004-2014 yılları arasındaki dönem için yaşam memnuniyeti bileşenlerinin birbirleriyle ilişkisini uygulamalı olarak inceledikleri çalışmada birim kök, granger nedensellik ve regresyon analizlerinden yararlanmışlardır. Elde edilen verilerin E-Views 8.0 programı ile analizi gerçekleştirilmiş ve yaşam memnuniyetini en çok etkileyen faktörler tespit edilmiştir. Çalışma sonucunda, ailenin genel mutluluğuna en çok sevgi ve sağlık hizmetleri etki ederken aile en az başarı ve asayiş hizmetlerinden etkilenmektedir. Bireylerin öz mutluluğu bakımından değerlendirildiğinde ise öz mutluluğun en çok para ve eğitim hizmetlerinden etkilendiği, sağlık ve SGK hizmetlerinden ise en az etkilendikleri sonucuna ulaşılmıştır. Aslangiray (2016), "Yaşam Memnuniyetini Etkileyen Faktörlerin Modellenmesi: Batı Akdeniz Örneği" adlı çalışmada 2013 yılına ait TÜiK tarafından yapılan yaşam memnuniyeti araştırması anket verilerini kullanmıştır. Çalışma ile Türkiye genelinde ve Batı Akdeniz Bölgesinde (Antalya, Isparta ve Burdur) yaşayanların yaşam memnuniyetlerini etkileyen faktörlerin belirlenmesi amaçlanmıştır. Yaşam memnuniyetini; hanehalkı büyüklüğü, konut mülkiyeti, 
konut özellikleri, hanehalkı geliri ve bu gelirin ihtiyaçları karşılama düzeyi gibi değişkenlerin etkilediği belirlenmiştir. Araştırmanın en önemli sonucu ise, Antalya ilinde yaşayan fertlerin yaşam memnuniyetlerinin ortalama her alanda ülkemiz genelinde, Isparta ve Burdur illerinde yaşayanların memnuniyetlerinden daha düşük derecede olmasıdır. Ağbektaş (2016), çalışmasında TÜİK'in yaşam memnuniyeti anket sorularını kullanarak, Sivas İl Merkezinde 980 kişiye 37 maddelik anket uygulamıştır. Analizler SPSS STATISTICS 22 paket programı ile yapılarak tahminler elde edilmiştir. Gelir durumu ve eğitim durumunun yaşam memnuniyeti üzerinde diğer değişkenlere göre daha etkili olduğu ancak kamu hizmetlerinden memnuniyet ve beklenti düzeyleri üzerinde gelir durumu ve eğitim durumu dışında yaş ve cinsiyetin de etkili olduğu tespit edilmiştir. Timur ve Akay (2017), TÜiK tarafından 2009 ve 2015 yıllarında gerçekleştirilen yaşam memnuniyeti araştırması verilerini kullanarak sosyo-demografik ve ekonomik değişkenlerin hanehalkı mutluluğu üzerindeki etkilerini mutluluk ekonomisi altında incelemişlerdir. Çalışmada model olarak genelleştirilmiş sıralı logit model kullanılarak analiz yapılmıştır. Kadınlar ve erkekler için ayrı ayrı mutluluğu belirleyen faktörler incelenmiş ve sonuç olarak ekonomik faktörlerin ve temel ihtiyaçların karşılanma düzeylerinin bireylerin mutluluğu üzerinde önemli bir etkiye sahip olduğu ortaya konulmuştur. Şehribanoğlu ve Diler (2018), çalışmada bireylerin mutluluğunu etkileyen değişkenleri veri madenciliği yöntemleri ile incelemişlerdir. Elde edilen bulgulara göre, hanehalkı geliri mutluluk ya da mutsuzluk kavramlarında ortaya çıkan ortak değişkendir. Kişilerin mutluluk algilarında para birinci sırada yer almaktadır.

\section{Yöntem}

Lojistik regresyon, kategoriler halinde ölçülmüş bağımlı değişken ile kategorik veya sürekli olarak ölçülmüş bazı bağımsız değişkenler arasındaki ilişkileri modellemek amacıyla kullanılmaktadır. Sıralı lojistik regresyon modeli ise bağımlı değişkenin en az üç kategoriden oluştuğu ve sıralı ölçekle ölçüldüğü durumlarda kullanılan bir yöntemdir (Demirtas, Anagun ve Koksal, 2009). Sıralı regresyon modelinde bağımsız değişkenlerin tümünün veya bazılarının sürekli ya da kategorik olmasına ilişkin bir zorunluluk bulunmamaktadır. Fakat araştırmalarda daha çok sürekli değişkenlerin tercih edilmesi önerilmektedir (Işığıçok, 2003). 
Sıralı lojistik regresyon modelinin başlıca özellikleri şu şekilde sayılabilir (Chen and Hughes, 2004):

- Söz konusu bağımlı değişken gözlemlenmemiş sürekli gizli (latent) bir değişken tarafından tekrar düzenlenebilir sıralı ve gruplanmış kategorik bir değişken olup sıralı değişkenin kategorileri arasındaki mesafenin eşit olup olmadığı kesin değildir.

- Normallik ve sabit varyans varsayımının sağlanmasını gerektirmeyen siralı lojistik regresyon analizinde bağımsız değişkenlerin sıralı kategorik değişkenler üzerindeki etkilerini açıklamak için bir bağlantı fonksiyonu kullanilır.

- Regresyon katsayısının değeri sıralı kategorik çıktı değişkeninin kategorilerine bağlı olmadığından dolayı sıralı lojistik regresyon modeli, açıklayıcı değişken ile sıralı kategorik çıtı değişkeni arasındaki ilişkinin kategorilerden bağımsız olduğunu varsayar.

Siralı Lojistik Regresyon modeli genel olarak, $\pi(x)=E(y \mid x)=P\{y=$ $1 \mid x\}$ olsun. $x$; bağımsız değişkenlerin $\left\{x_{1}, x_{2}, \ldots, x_{k}\right\}$ bir vektörü olmak üzere,

$$
\begin{aligned}
& \qquad \pi(x)=\frac{\exp \left(\beta_{0}+\beta_{1} x_{1}+\beta_{2} x_{2}+\cdots+\beta_{k} x_{k}\right)}{1+\exp \left(\beta_{0}+\beta_{1} x_{1}+\beta_{2} x_{2}+\cdots+\beta_{k} x_{k}\right)} \\
& =\frac{1}{1+\exp \left[-\left(\beta_{0}+\beta_{1} x_{1}+\beta_{2} x_{2}+\cdots+\beta_{k} x_{k}\right)\right]} \\
& \text { şeklinde ifade edilir (O'Connell, 2006; Frank ve Harrell, 2001). }
\end{aligned}
$$

\section{Sıralı Regresyon Analizinin Varsayımları}

Sıralı lojistik regresyon analizinde normallik, süreklilik, eşvaryanslılık ve çok değişkenli normallik gibi varsayımların sağlanması zorunluluğu olmadığı için model yapısında çeşitli bağlantı fonksiyonlarının kullanılması gerekmektedir. Çünkü bağlantı fonksiyonları, sıralı lojistik regresyon modellerini güçlü bir paralel eğriler varsayımı altında oluşturmaktadır. Sıralı lojistik regresyon analizinde bir modelin kurulabilmesi için paralel eğriler varsayımının sağlanması şartı bulunmaktadır. Paralel eğriler varsayımında tahmin edilen regresyon katsayıları sıralı kategorik değişkenin bütün kategorilerinde eşit sayılmaktadır (Şerbetçi ve Özçomak, 2013). 


\section{Paralel Ĕgriler Varsayımı}

Sıralı Lojistik Regresyonda Paralel Doğrular varsayımı, bağımlı değişkene ait kategorilerin birbirine paralelliğini gerektirir. Dolayısıyla aynı parametrelere sahip bütün kategorilerin uygunluğunu test eder (Akın ve Şentürk, 2012). Varsayım yerine gelmezse, değişik yaklaşımlar kullanılabilir. Bunlar şu şekilde sıralanabilir: bazı kategoriler az sayıda denek içeriyorsa, iki ya da daha fazla kategori birleştirilebilir, kısmi orantılı odds modeli kullanılabilir ya da multinominal lojistik regresyon analizi yapılabilir (Sümbüloğlu ve Akdağ, 2007)

Paralel eğriler varsayımının test edilmesinde "sıfır hipotezi" ve "alternatif hipotez" şu şekilde kurulur:

- $\quad H_{0}$ : İlişkili regresyon katsayıları, bağımlı değişkenin tüm kategorilerinde aynidir.

- $\quad H_{1}$ : Illişkili regresyon katsayıları, bağımlı değişkenin tüm kategorilerinde farklıdır.

Paralel eğriler varsayımı şartının sağlanmış olması elde edilen sonuçların doğruluğu ve güvenilirliği için gerekmektedir. Aksi durumda sonuçların hem yanlış hem de anlamsız olacağı bilinmektedir. Literatürde de bu varsayımın geçerliliğinin ve güvenirliliğinin ölçülmesi amacıyla kullanılan testler mevcuttur. Bunlar arasında; Wald Ki-kare Testi, Olabilirlik Oran Testi gibi testler sayılabilir (Eygü ve Güllüce, 2017).

\section{Bağlantı Fonksiyonları}

Sıralı lojistik regresyon analizinde yaygın olarak kullanılan beş çeşit bağlantı fonksiyonu bulunmaktadır. Bu bağlantı fonksiyonları Tablo-1'de gösterilmektedir.

Tablo 1. Băglantı Fonksiyonlan

\begin{tabular}{lll}
\hline Fonksiyon & Gösterim & Uygulama Alanları \\
\hline Logit & $\ln (\gamma / 1-\gamma)$ & Tüm kategorilerin olasılık değerleri eşit ise kullanılır. \\
\hline Tamamlayıcı Log-log & $\ln (-\ln (1-\gamma))$ & Yüksek kategorilerde olasılık değeri daha yüksek ise kullanılır. \\
\hline Negatif Log-log & $-\ln (-\ln (\gamma))$ & Düşük kategorilerde olasılık değeri daha yüksek ise kullanılır. \\
\hline Probit & $\varphi-1(\gamma)$ & $\begin{array}{l}\text { Normal dağılmış gizli değişken söz konusu olduğunda kulla- } \\
\text { nılır. }\end{array}$ \\
\hline Cauchit & $\tan$ & Birçok uç değerin olduğu kategori varsa kullanılır. \\
& $(\pi(\gamma-0,5))$ & \\
\hline
\end{tabular}

Kaynak: (Şerbetçi ve Özçomak, 2013). 
Literatürde hangi duruma göre hangi bağlantı fonksiyonun kullanılması gerektiği ile ilgili kesin bir kural bulunmamakla birlikte kategorilerin birikimli olasılık yoğunluk fonksiyonunda ani bir değişim olmuyorsa logit ve probit fonksiyonları, ani bir değişim oluyorsa tamamlayıcı log-log, negatif log-log ve couchit fonksiyonlarının kullanılması tercih edilmektedir (Şerbetçi, 2012).

\section{Modelin Uygunluğunun Test Edilmesi}

Modelin kurulmasından sonraki aşamada kurulan modelin uygunluğunun test edilmesi gerekmektedir. Buradaki amaç, kurulan modelin araştırmadaki verilere uygun olup olmadığının kontrol edilmesidir. Bu işlem için sıralı lojistik regresyon analizinde genellikle Pearson $X^{2}$ istatistiği, Cox ve Snell $X^{2}$ istatistiği, Mc Fadden $X^{2}$ istatistiği ve Nagelkerke $X^{2}$ istatistiği gibi çeşitli istatistikler kullanılmaktadır (Orçanll, Oktay ve Birgören, 2018).

Modelin genel geçerliliğini test eden sıfır ve alternatif hipotezler ise,

- $H_{0}$ : Model verileri iyi temsil etmektedir.

- $H_{1}$ : Model verileri iyi temsil etmemektedir.

şeklinde ifade edilmektedir. Modelin geçerli olabilmesi için sıfır hipotezinin kabul edilmesi gerekmektedir (Kalayc1, 2010).

\section{Bulgular ve Tartışma}

Tablo 2. Logit Modelde Kullanılan Bağımsız Değişkenlere Ait Tanımlayıcı İstatistikler

\begin{tabular}{|c|c|c|c|}
\hline Değişkenler & Tanımlamaları & Ortalama & St. Hata \\
\hline \multicolumn{4}{|c|}{ Bağımlı Değişkenler } \\
\hline & Mutluluk Düzeyi & & \\
\hline & 1.Mutlu (Çok Mutlu=1, Mutlu=1, Diğer=0) & 0.575 & 0.494 \\
\hline & 2.Orta $($ Orta $=1$, Diğer $=0)$ & 0.326 & 0.469 \\
\hline & 3.Mutsuz (Mutsuz=1, Çok Mutsuz=1, Diğer=0) & 0.099 & 0.299 \\
\hline \multicolumn{4}{|c|}{ Bağımsız Değişkenler } \\
\hline & Sağlığınızdan Memnun musunuz? & & \\
\hline & 1.Memnun (Çok Memnun=1, Memnun =1, Diğer=0) & 0.703 & 0.457 \\
\hline & 2. Orta (Orta $=1$, Diğer $=0)$ & 0.155 & 0.362 \\
\hline & $\begin{array}{l}\text { 3. Memnun Değil (Hiç Memnun Değil=1, Memnun } \\
\text { Değil=1, } \\
\text { Diğer=0) }\end{array}$ & 0.142 & 0.349 \\
\hline
\end{tabular}




\begin{tabular}{|c|c|c|}
\hline \multicolumn{3}{|l|}{$\begin{array}{l}\text { Şimdiye kadar almış olduğunuz eğitimden memnun } \\
\text { musunuz? }\end{array}$} \\
\hline 1. Memnun (Çok Memnun=1, Memnun =1, Diğer=0) & 0.485 & 0.500 \\
\hline 2. Orta (Orta $=1$, Diğer $=0)$ & 0.107 & 0.309 \\
\hline \multicolumn{2}{|c|}{$\begin{array}{l}\text { 3. Memnun Değil (Hiç Memnun Değil=1, Memnun De- } 0.323 \\
\text { ğil=1, Diğer=0) }\end{array}$} & 0.468 \\
\hline \multicolumn{3}{|l|}{ Aylık Hane Halkı Gelirinizden Memnun Musunuz? } \\
\hline 1. Memnun (Çok Memnun=1, Memnun =1, Diğer=0) & 0.469 & 0.499 \\
\hline 2. Orta $($ Orta $=1$, Diğer $=0)$ & 0.190 & 0.392 \\
\hline \multicolumn{2}{|c|}{$\begin{array}{l}\text { 3. Memnun Değil (Hiç Memnun Değil=1, Memnun De- } 0.341 \\
\text { ğil=1, Diğer=0) }\end{array}$} & 0.474 \\
\hline \multicolumn{3}{|c|}{ Sosyal hayatınıdan memnun musunuz? } \\
\hline 1. Memnun (Çok Memnun=1, Memnun =1, Diğer=0) & 0.523 & 0.500 \\
\hline 2. Orta (Orta $=1$, Diğer $=0)$ & 0.162 & 0.369 \\
\hline $\begin{array}{l}\text { 3. Memnun Değil (Hiç Memnun Değil=1, Memnun } \\
\text { Değil=1, Diğer=0) }\end{array}$ & 0.315 & 0.465 \\
\hline \multicolumn{3}{|l|}{ Akrabalarınızla ilişkilerinizden memnun musunuz? } \\
\hline 1. Memnun (Çok Memnun=1, Memnun =1, Diğer=0) & 0.792 & 0.406 \\
\hline 2. Orta (Orta $=1$, Diğer $=0)$ & 0.103 & 0.305 \\
\hline $\begin{array}{l}\text { 3. Memnun Değil (Hiç Memnun Değil=1, Memnun } \\
\text { Değil=1, Diğer=0) }\end{array}$ & 0.105 & 0.306 \\
\hline \multicolumn{3}{|l|}{ Asayiş (güvenlik) hizmetlerinden memnun musunuz? } \\
\hline 1. Memnun (Çok Memnun=1, Memnun =1, Diğer=0) & 0.840 & 0.366 \\
\hline 2. Orta (Orta $=1$, Diğer $=0)$ & 0.078 & 0.269 \\
\hline $\begin{array}{l}\text { 3. Memnun Değil (Hiç Memnun Değil=1, Memnun } \\
\text { Değil=1, Diğer=0) }\end{array}$ & 0.081 & 0.274 \\
\hline \multicolumn{3}{|l|}{ Ulaştırma hizmetlerinden memnun musunuz? } \\
\hline 1. Memnun (Çok Memnun=1, Memnun =1, Diğer=0) & 0.793 & 0.405 \\
\hline 2. Orta (Orta $=1$, Diğer $=0)$ & 0.067 & 0.250 \\
\hline $\begin{array}{l}\text { 3. Memnun Değil (Hiç Memnun Değil=1, Memnun } \\
\text { Değil=1, Diğer=0) }\end{array}$ & 0.098 & 0.297 \\
\hline \multicolumn{3}{|l|}{ Kendinize ayırdığınız zamandan memnun musunuz? } \\
\hline 1. Memnun (Çok Memnun=1, Memnun =1, Diğer=0) & 0.566 & 0.496 \\
\hline 2. Orta (Orta=1, Diğer $=0)$ & 0.144 & 0.351 \\
\hline $\begin{array}{l}\text { 3. Memnun Değil (Hiç Memnun Değil=1, Memnun } \\
\text { Değil=1, Diğer=0) }\end{array}$ & 0.290 & 0.454 \\
\hline \multicolumn{3}{|l|}{ Medeni Durum } \\
\hline 1.Hiç Evlenmemiş (Hiç evlenmedi=1,Diğer=0) & 0.128 & 0.335 \\
\hline 2.Evli (Evli=1, Diğer=0) & 0.797 & 0.402 \\
\hline 3. Boşandı (Boşandı=1, Diğer=0) & 0.016 & 0.125 \\
\hline 4.Eşi Öldü (Eşi öldü=1, Diğer=0) & 0.059 & 0.235 \\
\hline \multicolumn{3}{|l|}{ En son hangi okulu bitirdiniz? } \\
\hline 1. Okul Bitirmedi (Okul bitirmedi=1,Diğer=0) & 0.110 & 0.313 \\
\hline 2. İlkokul. İlköğretim (İlkokul=1, İköğretim=1, Diğer=0) & 0.459 & 0.498 \\
\hline $\begin{array}{l}\text { 3. Genel Ortaokul, Mesleki veya Teknik Ortaokul(Gen } \\
\text { ortaokul=1, Mesleki veya Teknik Ortaokul=1, Diğer=0) }\end{array}$ & 10.074 & 0.262 \\
\hline
\end{tabular}


4.Genel Lise, Mesleki veya Teknik Lise (Genel Lise $=1,0.209 \quad 0.407$

Mesleki veya Teknik Lise $=1$, Diğer $=0$ )

5. Yükseköğretim (İki veya Üç Ylllı Yüksekokul=1, Dört $0.135 \quad 0.342$

Ylllık Yüksekokul veya Fakülte=1, Yüksek Lisans/Dok-

tora $=1$, Diğer $=0$ )

Son bir hafta içinde ücretli ya da ücretsiz olarak bir işte

çalıştınız mı?

\begin{tabular}{lll}
\hline 1. Çalıştı (Çalıştı=1, Diğer=0) & 0.266 & 0.442 \\
\hline 2. Çalışmadı fakat İlgisi devam ediyor (Orta=1, Diğer=0) & 0.029 & 0.167 \\
\hline 3. Çalışmadı (Çalışmadı=1, Diğer=0) & 0.705 & 0.456
\end{tabular}

Tablo 2 incelendiğinde araştırmaya katılan bireylerle ilgili olarak:

- Sağlık durumundan memnuniyetleri ile ilgili; \%70.3'ünün memnun, $\% 15.5$ 'inin orta ve \%14.2' inin ise memnun olmadığ1,

- Eğitim durumundan memnuniyetleri ile ilgili; \%48.5'inin memnun, \%10.7'inin orta ve \%32.3'ünün ise memnun olmadığı,

- Gelir durumundan memnuniyetleri ile ilgili; \%46.9'unun memnun, \%19'unun orta ve \%34.1'inin ise memnun olmadığ1,

- Sosyal hayat durumundan memnuniyetleri ile ilgili; \%52.3'ünün memnun, \%16.2 'inin orta ve \%31.5' inin ise memnun olmadığ 1 ,

- Akraba ilişkilerinden memnuniyet ile ilgili; \%79.2'inin memnun, \%10.3 'ünün orta ve \%10.5'inin ise memnun olmadığı,

- Asayiş hizmetlerinden memnuniyet ile ilgili; \%84'ünün memnun, \%7.8 'inin orta ve \%8.1'inin ise memnun olmadığı,

- Ulaştırma hizmetlerinden memnuniyet ile ilgili; \%79.3'ünün memnun, \%6.7'inin orta ve \%9.8'inin ise memnun olmadığı,

- Bireyin kendisine ayırdığı zamandan duyduğu memnuniyet ile ilgili; $\% 56.6$ 'inun memnun, \%14.4'ünün orta ve \%29'unun ise memnun olmadiğl,

- Medeni durumları ile ilgili; \%12.8'i hiç evlenmemiş, \%79.7'i evli, \%1.6'1 boşanmış ve \% 5.9'nun eşinin ölmüş olduğu,

- Okul bitirme durumu ile ilgili; \%11'nin bir okul bitirmediği, \%45.9'unun ilkokul ve ilköğretim, \%7.4'ünün genel ortaokul ve mesleki veya teknik ortaokul, \%20.9'unun lise ve \% 13.5'inin yükseköğretim mezunu olduğu,

- Çalışma durumları ile ilgili; \%26.6'ının çalıştığı, \%2.9'unun çalışmıyor ancak işiyle ilgisinin devam ettiği ve \%70.5'inin çalışmıyor olduğu belirlenmiştir. 


\section{Modelin Kurulması}

Tablo 2' de yer alan Yaşam Memnuniyetinin bağımlı diğerlerinin ise bağımsız değişken olarak belirlenmesinin ardından kurulacak olan model şu şekildedir:

$$
\begin{gathered}
\mathrm{Y}=\beta_{0}+\beta_{1} X_{1}+\beta_{2} X_{2}+\beta_{3} X_{3}+\beta_{4} X_{4}+\beta_{5} X_{5}+\beta_{6} X_{6}+\beta_{7} X_{7}+\beta_{8} X_{8}+ \\
+\beta_{9} X_{9}+\beta_{10} X_{10}+\beta_{11} X_{11}+\beta_{12} X_{12}+\beta_{13} X_{13}+\beta_{14} X_{14}+\beta_{15} X_{15}+\beta_{16} X_{16}+\epsilon
\end{gathered}
$$

- Y: Mutluluk Düzeyini,

- $\beta$ : Model parametrelerini,

- $\quad X$ :Sağlığınızdan memnun musunuz "Memnun", (Rfr: Memnun Değil),

- $X_{2}$ : Sağlığınızdan memnun musunuz "Orta”, (Rfr: Memnun Değil),

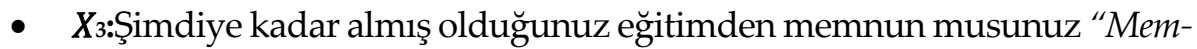
nun", (Rfr: Memnun Değil),

- $X_{4}$ : Aylık hanehalkı gelirinizden memnun musunuz "Memnun", (Rfr: Memnun Değil),

- $X_{5}$ :Aylık hanehalkı gelirinizden memnun musunuz "Orta", (Rfr: Memnun Değil),

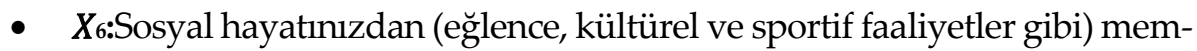
nun musunuz "Memnun", (Rfr: Memnun Değil),

- $\quad X_{7}$ :Sosyal hayatınızdan (eğlence, kültürel ve sportif faaliyetler gibi) memnun musunuz "Orta", (Rfr: Memnun Değil),

- $\quad X_{8}$ :Akrabalarınızla ilişkilerinizden memnun musunuz "Memnun", (Rfr: Memnun Değil),

- $\quad X$ 9:Akrabalarınızla ilişkilerinizden memnun musunuz "Orta", (Rfr: Memnun Değil),

- $X_{10}$ :Asayiş (güvenlik) hizmetlerinden memnun musunuz "Memnun", (Rfr: Memnun Değil),

- X11:Asayiş (güvenlik) hizmetlerinden memnun musunuz "Orta", (Rfr: Memnun Değil),

- X12:Ulaştırma hizmetlerinden memnun musunuz "Memnun", (Rfr: Memnun Değil),

- X13: En son hangi okulu bitirdiniz "Illkokul, İlköğretim", (Rfr: Bir Okul Bitirmedi), 
- $\quad X_{14}:$ Son bir hafta içinde ücretli ya da ücretsiz olarak bir işte çalıştınız mı "Çalışmadı Fakat İlgisi Devam Ediyor", (Rfr: Çalışmadı),

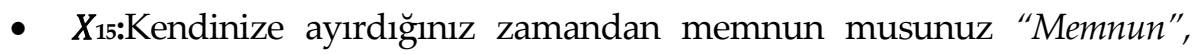
(Rfr: Memnun Değil),

- $\quad X_{16}$ :Bireyin medeni durumu "Evli", (Rfr: Eşi Öldü) ve

- $\epsilon$ : Hata Terimini belirtmektedir.

\section{Modelin Tahmin Sonuçlarn}

Model tahmin sonuçlarına geçmeden önce modelin paralellik varsayımını sağlayıp sağlamadığı kontrol edilmelidir. Paralel regresyon varsayımının test edilmesi için gerekli hipotezler;

- H0: İlişkili regresyon katsayıları bă̆gmlı değişkenin tüm kategorilerinde aynıdır.

- H1: Ilişkili regresyon katsayıları bağımlı değiş̧kenin tüm kategorilerinde aynı değildir.

Bu hipotezler altında paralel eğriler varsayımı için yapılan testte elde edilen veriler Tablo 3 'te verilmiştir.

Tablo 3: Paralel Ĕgriler Testi

\begin{tabular}{|c|c|c|c|c|}
\hline \multicolumn{2}{|c|}{-2 Log Likelihood } & \multirow[t]{2}{*}{$x^{x^{2}}$ Değeri } & \multirow[t]{2}{*}{ s.d } & \multirow[t]{2}{*}{ p } \\
\hline Ho hipotezi & 5810,641 & & & \\
\hline Genel & 5722,599 & 88,043 & 123 & 0.993 \\
\hline
\end{tabular}

Burada paralel eğriler varsayımı testinin $\mathrm{p}$ değeri 0,993 olup bu değer 0,05'ten büyük olduğu için $(0.993>0,05)$ paralel eğriler varsayımı testinin sıfır hipotezi reddedilemez. Dolayısıyla regresyon katsayılarının, bağımlı değişkenin bütün kategorileri için aynı olduğu kabul edilir.

Modelin uyum iyiliği testi ise Pearson $\chi^{2}$ ve sapma istatistiklerinden yararlanılarak Tablo 4'de verilmiştir.

Tablo 4. Uyum İyiliği Testi

\begin{tabular}{llll}
\hline Model & $\boldsymbol{x}^{2}$ & s.d & $\mathbf{P}$ \\
\hline Pearson & 8910,809 & 9351 & 0.999 \\
\hline Sapma & 5593,285 & 9351 & 1.000 \\
\hline
\end{tabular}

$\mathrm{H} 0=$ Model verileri uygundur.

$\mathrm{H}_{1}=$ Model verileri uygun değildir. 
Tablo 4'den görüldüğg̈u gibi $\mathrm{p}>0,05$ olduğu için modelin verilerle uyum içinde olduğu ve istatistiksel olarak anlamlı bulunarak sıfır hipotezi kabul edilmiştir.

Daha sonra kurulan model için Pseudo $R^{2}$ değerlerinin incelenmesi gerekmektedir. Pseudo $R^{2}$ değerleri, bağımsız değişkenlerin, bağımlı değişkenleri ne derece açıkladığını göstermektedir. Pseudo $R^{2}$ değerleri Tablo $5^{\prime}$ te verilmiştir.

Tablo 5. Pseudo $R^{2}$ Değerleri

\begin{tabular}{ll}
\hline Cox and Snell & 0,230 \\
\hline Nagelkerke & 0,250 \\
\hline McFadden & 0,103 \\
\hline
\end{tabular}

Pseudo $R^{2}$ değerleri sirasiyla Cox ve Snell $(0,230)$, Nagelkerte $(0,250)$ ve McFadden $(0,103)$ olarak hesaplanmıştır. Pseudo $R^{2}$ istatistik değerlerinden Cox ve Snell istatistik değerinin yorumlamasının zor olmasından dolayı Nagelkerke istatistik değerine bakılmaktadır. Bu değer bağımlı değişkenin yüzde kaçının bağımsız değişkenler tarafından açıkladığını göstermektedir. Pseudo $R^{2}$ istatistik değerleri, lojistik regresyon analizinde iyi bir ölçüt olmadığı için analizlerde genellikle düşük çıkmaktadır (Orçanlı, Oktay ve Birgören, 2018).

Tablo 6. Stralı Logit Model Tahmini

\begin{tabular}{|c|c|c|c|c|c|c|c|}
\hline Log Likelihood=-3156.4118 & & & & & & $\begin{array}{l}\text { Gözle } \\
\text { LR chi } \\
\text { Prob }> \\
\text { Pseud }\end{array}$ & $\begin{array}{l}y 1 S 1=2786 \\
=727.02 \\
=0.000 \\
=0.1033\end{array}$ \\
\hline Bağımsız Değişkenler & B & $\begin{array}{l}\text { St. } \\
\text { Hata }\end{array}$ & $\mathbf{Z}$ & $\mathrm{P}>\mathrm{IzI}$ & e $\beta$ & $\begin{aligned} & \mathbf{( 9 5 \%} \\
& \text { interv }\end{aligned}$ & \\
\hline $\begin{array}{l}\text { Sağlığınızdan memnun musunuz } \\
\text { (Memnun) }\end{array}$ & -1.111 & .113 & -9.79 & $0.000(* * *)$ & .329 & -1.333 & -.888 \\
\hline $\begin{array}{l}\text { Sağlığınızdan memnun musunuz } \\
\text { (Orta) }\end{array}$ & -.601 & .135 & -4.45 & $0.000(* * *)$ & .548 & -.866 & -.336 \\
\hline $\begin{array}{l}\text { Şimdiye kadar almış olduğunuz } \\
\text { eğitimden memnun musunuz } \\
\text { (Memnun) }\end{array}$ & -.194 & .089 & -2.17 & $0.030(* *)$ & .823 & -.370 & -.019 \\
\hline $\begin{array}{l}\text { Aylı hanehalkı gelirinizden } \\
\text { memnun musunuz (Memnun) }\end{array}$ & -.868 & .093 & -9.29 & $0.000(* * *)$ & .420 & -1.051 & -.685 \\
\hline $\begin{array}{l}\text { Aylık hanehalkı gelirinizden } \\
\text { memnun musunuz (Orta) }\end{array}$ & -.498 & .109 & -4.59 & $0.000(* * *)$ & .608 & -.710 & -.285 \\
\hline $\begin{array}{l}\text { Sosyal hayatınızdan } \\
\text { memnun musunuz (Memnun) }\end{array}$ & -.586 & .107 & -5.48 & $0.000(* * *)$ & .557 & -.795 & -.377 \\
\hline
\end{tabular}




\begin{tabular}{|c|c|c|c|c|c|c|c|}
\hline $\begin{array}{l}\text { Sosyal hayatınızdan memnun } \\
\text { musunuz (Orta) }\end{array}$ & -.444 & .129 & -3.43 & $0.001(* * *)$ & .641 & -.698 & -.190 \\
\hline $\begin{array}{l}\text { Akrabalarınızla ilişkilerinizden } \\
\text { memnun musunuz (Memnun) }\end{array}$ & -.995 & .142 & -6.99 & $0.000(* * *)$ & .370 & -1.274 & -.716 \\
\hline $\begin{array}{l}\text { Akrabalarınızla ilişkilerinizden } \\
\text { memnun musunuz (Orta) }\end{array}$ & -.779 & .176 & -4.41 & $0.000(* * *)$ & .459 & -1.124 & -.433 \\
\hline $\begin{array}{l}\text { Asayiş hizmetlerinden memnun } \\
\text { musunuz (Memnun) }\end{array}$ & -.381 & .151 & -2.53 & $0.011(* *)$ & .683 & -.677 & -.086 \\
\hline $\begin{array}{l}\text { Asayiş hizmetlerinden memnun } \\
\text { musunuz ( Orta) }\end{array}$ & -.409 & .195 & -2.10 & $0.036(* *)$ & .664 & -.790 & -.027 \\
\hline $\begin{array}{l}\text { Ulaştırma hizmetlerinden mem- } \\
\text { nun musunuz (Memnun) }\end{array}$ & .212 & .112 & 1.89 & $0.059(*)$ & 1.236 & -.008 & .432 \\
\hline $\begin{array}{l}\text { En son hangi okulu bitirdiniz (ìl- } \\
\text { kokul, Illkögretim) }\end{array}$ & .224 & .125 & 1.79 & $0.074(*)$ & 1.251 & -.022 & .469 \\
\hline $\begin{array}{l}\text { Son bir hafta içinde ücretli ya da } \\
\text { ücretsiz olarak bir işte çalıştınız mı } \\
\text { ( Çalışmadı fakat ilgilisi devam } \\
\text { ediyor) }\end{array}$ & .681 & .223 & 3.05 & $0.002(* * *)$ & 1.976 & .243 & 1.119 \\
\hline $\begin{array}{l}\text { Kendinize ayırdığınız zamandan } \\
\text { memnun musunuz (Memnun) }\end{array}$ & -.319 & .105 & -3.03 & $0.002(* * *)$ & .727 & -.525 & -.113 \\
\hline Medeni Durum (Evli) & -.562 & .164 & -3.44 & $0.001(* * *)$ & .570 & -.883 & -.242 \\
\hline-5.828 & & .326 & & & & -6.467 & -5.188 \\
\hline-3.136 & & .316 & & & & -3.755 & -2.517 \\
\hline-0.813 & & .309 & & & & -1.418 & -0.207 \\
\hline 0.591 & & .317 & & & & -0.030 & 1.212 \\
\hline
\end{tabular}

Notlar: (i) ${ }^{* * * * *}$ ve ${ }^{*}$ sirasiyla $\% 1, \% 5$ ve $\% 10$ istatistiksel önem seviyesini ifade etmektedir.

(ii) $\mu^{\prime}$ ler kesim noktalarını (uç değerleri) göstermektedir.

(iii) $\beta^{\prime}$ lar tahmin edilen katsayı değerlerini göstermektedir.

Sıralı lojistik regresyon analizinin sonuçlarının yer verildiği Tablo 6'da referans kategori her bir bağımsız değişken için son kategori olarak belirlenmiş ve yorumlar buna göre yapılmıştır.

- Sağlık Durumundan Memnuniyet (Rfr: Memnun Değil): Sağlığınızdan memnun musunuz ifadesine "Memnun" cevabı verenler ile yaşam memnuniyeti değişkeni arasında istatistiksel olarak anlamlı bir ilişki bulunmuştur. Buna göre; sağlığınızdan memnun musunuz değişkeni üzerindeki 1 birimlik değişimin yaşam memnuniyeti değişkeni üzerinde 0.32 'lik bir azalmaya neden olduğu söylenebilir.

- Sağlık Durumundan Memnuniyet (Rfr: Memnun Değil): Sağlığınızdan memnun musunuz ifadesine "Orta Derece Memnun" cevabı verenler ile yaşam memnuniyeti değişkeni arasında istatistiksel olarak anlamlı 
bir ilişki bulunmuştur. Buna göre; sağlığınızdan memnun musunuz değişkeni üzerindeki 1 birimlik değişimin yaşam memnuniyeti değişkeni üzerinde 0.54 'lük bir azalmaya neden olduğu söylenebilir.

- Eğitim Durumundan Memnuniyet (Rfr: Memnun Değil): Şimdiye kadar almış olduğunuz eğitimden memnun musunuz ifadesine "Memnun" cevabı verenler ile yaşam memnuniyeti değişkeni arasında istatistiksel olarak anlamlı bir ilişki bulunmuştur. Buna göre; Şimdiye kadar almış olduğunuz eğitimden memnun musunuz değişkeni üzerindeki 1 birimlik değişimin yaşam memnuniyeti değişkeni üzerinde 0.82 'lik bir azalmaya neden olduğu söylenebilir.

- Gelir Durumundan Memnuniyet (Rfr: Memnun Değil): Aylık hanehalkı gelirinizden memnun musunuz ifadesine "Memnun" cevabı verenler ile yaşam memnuniyeti değişkeni arasında istatistiksel olarak anlamlı bir ilişki bulunmuştur. Buna göre; aylık hanehalkı gelirinden memnun musunuz değişkeni üzerindeki 1 birimlik değişimin yaşam memnuniyeti değişkeni üzerinde 0.42 'lik bir azalmaya neden olduğu söylenebilir.

- Gelir Durumundan Memnuniyet (Rfr: Memnun Değil): Aylık hanehalkı gelirinizden memnun musunuz ifadesine "Orta Derece Memnun" cevabı verenler ile yaşam memnuniyeti değişkeni arasında istatistiksel olarak anlamlı bir ilişki bulunmuştur. Buna göre; aylık hanehalkı gelirinden memnun musunuz değişkeni üzerindeki 1 birimlik değişimin yaşam memnuniyeti değişkeni üzerinde $0.60^{\prime} l \mathrm{lk}$ bir azalmaya neden olduğu söylenebilir.

- Sosyal Hayat Durumundan Memnuniyet (Rfr: Memnun Değil): Sosyal hayatınızdan memnun musunuz ifadesine "Memnun" cevabı verenler ile yaşam memnuniyeti değiş̧keni arasında istatistiksel olarak anlamlı bir ilişki bulunmuştur. Buna göre; sosyal hayatınızdan memnun musunuz değişkeni üzerindeki 1 birimlik değişimin yaşam memnuniyeti değişkeni üzerinde 0.55 'lik bir azalmaya neden olduğu söylenebilir.

- Sosyal Hayat Durumundan Memnuniyet (Rfr: Memnun Değil): Sosyal hayatınızdan memnun musunuz ifadesine "Orta Derece Memnun" cevabı verenler ile yaşam memnuniyeti değişkeni arasında istatistiksel olarak anlamlı bir ilişki bulunmuştur. Buna göre; sosyal hayatınızdan memnun musunuz değişkeni üzerindeki 1 birimlik değişimin yaşam memnuniyeti değişkeni üzerinde 0.64 'lük bir azalmaya neden olduğu söylenebilir. 
- Akraba İlişkilerinden Memnuniyet (Rfr: Memnun Değil): Akraba ilişkilerinizden memnun musunuz ifadesine "Memnun" cevabı verenler ile yaşam memnuniyeti değişkeni arasında istatistiksel olarak anlamlı bir ilişki bulunmuştur. Buna göre; akraba ilişkilerinizden memnun musunuz değişkeni üzerindeki 1 birimlik değişimin yaşam memnuniyeti değişkeni üzerinde 0.37 'lik bir azalmaya neden olduğu söylenebilir.

- Akraba İlişkilerinden Memnuniyet (Rfr: Memnun Değil): Akraba ilişkilerinizden memnun musunuz ifadesine "Orta Derece Memnun" cevabı verenler ile yaşam memnuniyeti değişkeni arasında istatistiksel olarak anlamlı bir ilişki bulunmuştur. Buna göre; akraba ilişkilerinizden memnun musunuz değişkeni üzerindeki 1 birimlik değişimin yaşam memnuniyeti değişkeni üzerinde $0.45^{\prime}$ lik bir azalmaya neden olduğu söylenebilir.

- Asayiş Hizmetlerinden Memnuniyet (Rfr: Memnun Değil): Asayiş hizmetlerinden memnun musunuz ifadesine "Memnun" cevabı verenler ile yaşam memnuniyeti değişkeni arasında istatistiksel olarak anlamlı bir ilişki bulunmuştur. Buna göre; asayiş hizmetlerinden memnun musunuz değişkeni üzerindeki 1 birimlik değişimin yaşam memnuniyeti değişkeni üzerinde $0.68^{\prime}$ lik bir azalmaya neden olduğu söylenebilir.

- Asayiş Hizmetlerinden Memnuniyet (Rfr: Memnun Değil): Asayiş hizmetlerinden memnun musunuz ifadesine "Orta Derece Memnun" cevabı verenler ile yaşam memnuniyeti değişkeni arasında istatistiksel olarak anlamlı bir ilişki bulunmuştur. Buna göre; asayiş hizmetlerinden memnun musunuz değişkeni üzerindeki 1 birimlik değişimin yaşam memnuniyeti değişkeni üzerinde $0.66^{\prime}$ lık bir azalmaya neden olduğu söylenebilir.

- Ulaştırma Hizmetlerinden Memnuniyet (Rfr: Memnun Değil): Ulaştırma hizmetlerinden memnun musunuz ifadesine "Memnun" cevabı verenler ile yaşam memnuniyeti değişkeni arasında istatistiksel olarak anlamlı bir ilişki bulunmuştur. Buna göre; ulaştırma hizmetlerinden memnun musunuz değişkeni üzerindeki 1 birimlik değişimin yaşam memnuniyeti değişkeni üzerinde 1,23'lük bir artışa neden olduğu söylenebilir.

- Kişisel Bakım Hizmetlerinden Memnuniyet (Rfr: Memnun Değil): Kişisel bakım hizmetlerinden memnun musunuz ifadesine "Memnun" ce- 
vabı verenler ile yaşam memnuniyeti değişkeni arasında istatistiksel olarak anlamlı bir ilişki bulunmuştur. Buna göre; kişisel bakım hizmetlerinden memnun musunuz değişkeni üzerindeki 1 birimlik değişimin yaşam memnuniyeti değişkeni üzerinde 0.72 'lik bir azalmaya neden olduğu söylenebilir.

- Okul Bitirme Durumu(Rfr: Bir Okul Bitirmedi): Okul bitirme durumu "İlkokul-Ilköğretim" olanlar ile yaşam memnuniyeti değişkeni arasında istatistiksel olarak anlamlı bir ilişki bulunmuştur. Buna göre; okul bitirme durumu değişkeni üzerindeki 1 birimlik değişimin yaşam memnuniyeti değişkeni üzerinde 1,25'lik bir artışa neden olduğu söylenebilir.

- Çalışma Durumu (Rfr: Çalışmadı): Çalışma durumu "Çalışmadı fakat işi ile ilgisi devam ediyor" değişkeni ile yaşam memnuniyeti değişkeni arasında istatistiksel olarak anlamlı bir ilişki bulunmuştur. Buna göre; çalı̧̧ma durumu değişkeni üzerindeki 1 birimlik değişimin yaşam memnuniyeti değişkeni üzerinde 1,97'lik bir artışa neden olduğu söylenebilir.

- Medeni Durum (Rfr: Eşi Öldü): Medeni durumu “Evli” değişkeni ile yaşam memnuniyeti değişkeni arasında istatistiksel olarak anlamlı bir ilişki bulunmuştur. Buna göre; medeni durum değişkeni üzerindeki 1 birimlik değişimin yaşam memnuniyeti değişkeni üzerinde $0,57^{\prime}$ lik bir azalışa neden olduğu söylenebilir.

Tablo 7. Marjinal Etkiler

\begin{tabular}{|c|c|c|c|c|c|c|}
\hline \multirow{2}{*}{$\begin{array}{l}\text { Bağımsız Değişkenler } \\
\begin{array}{l}\text { Sağlığınızdan memnun } \\
\text { musunuz (Memnun) }\end{array}\end{array}$} & \multirow{2}{*}{$\begin{array}{l}\mathrm{dy} / \mathrm{dx} \\
-.476\end{array}$} & \multirow{2}{*}{$\begin{array}{l}\text { St. Hata } \\
.046\end{array}$} & \multirow{2}{*}{$\begin{array}{c}T \\
-10.38\end{array}$} & \multirow{2}{*}{$\begin{array}{l}\mathbf{P}>\mathbf{I t I} \\
0.000(* * *)\end{array}$} & \multicolumn{2}{|c|}{$\begin{array}{l}\text { (95\% Conf. } \\
\text { interval) }\end{array}$} \\
\hline & & & & & -.566 & -.386 \\
\hline Sağlığınızdan memnun musunuz (Orta) & -.286 & .056 & -5.10 & $0.000(* * *)$ & -.396 & -.176 \\
\hline $\begin{array}{l}\text { Şimdiye kadar almış olduğunuz eğitimden } \\
\text { memnun musunuz (Memnun) }\end{array}$ & -.081 & .037 & -2.22 & $0.027(* *)$ & -.153 & -.009 \\
\hline $\begin{array}{l}\text { Aylık hanehalkı gelirinizden memnun musu- } \\
\text { nuz (Memnun) }\end{array}$ & -.346 & .038 & -9.22 & $0.000(* * *)$ & -.419 & -.272 \\
\hline $\begin{array}{l}\text { Aylık hanehalkı gelirinizden memnun musu- } \\
\text { nuz (Orta) }\end{array}$ & -.210 & .044 & -4.72 & $0.000(* * *)$ & -.297 & -.123 \\
\hline $\begin{array}{l}\text { Sosyal hayatınizdan memnun musunuz } \\
\text { (Memnun) }\end{array}$ & -.235 & .043 & -5.45 & $0.000(* * *)$ & -.320 & -.151 \\
\hline Sosyal hayatınızdan memnun musunuz (Orta) & -.186 & .053 & -3.51 & $0.000(* * *)$ & -.290 & -.082 \\
\hline $\begin{array}{l}\text { Akrabalarınızla ilişskilerinizden memnun mu- } \\
\text { sunuz (Memnun) }\end{array}$ & -.434 & .057 & -7.58 & $0.000(* * *)$ & -.547 & -.322 \\
\hline $\begin{array}{l}\text { Akrabalarınızla ilişkilerinizden memnun mu- } \\
\text { sunuz (Orta) }\end{array}$ & -.359 & .073 & -4.95 & $0.000(* * *)$ & -.502 & -.217 \\
\hline $\begin{array}{l}\text { Asayiş hizmetlerinden memnun musunuz } \\
\text { (Memnun) }\end{array}$ & -.176 & .062 & -2.83 & $0.005(* * *)$ & -.297 & -.054 \\
\hline
\end{tabular}




\begin{tabular}{|c|c|c|c|c|c|c|}
\hline $\begin{array}{l}\text { Asayiş hizmetlerinden memnun musunuz ( } \\
\text { Orta) }\end{array}$ & -.188 & .081 & -2.33 & $0.020(* *)$ & -.347 & -.030 \\
\hline $\begin{array}{l}\text { Ulaştırma hizmetlerinden memnun musunuz } \\
\text { (Memnun) }\end{array}$ & .097 & .046 & 2.10 & $0.036(* *)$ & .006 & .187 \\
\hline $\begin{array}{l}\text { Son bir hafta içinde ücretli ya da ücretsiz ola- } \\
\text { rak bir işte çalıştınız mı ( Çalışmadı fakat ilgisi } \\
\text { devam ediyor) }\end{array}$ & .268 & .091 & 2.94 & $0.003(* * *)$ & .089 & .446 \\
\hline $\begin{array}{l}\text { Kendinize ayırdığınız zamandan memnun } \\
\text { musunuz (Memnun }\end{array}$ & -.141 & .043 & -3.30 & $0.001(* * *)$ & -.225 & -.057 \\
\hline Medeni Durum (Evli) & -.249 & .068 & -3.68 & $0.000(* * *)$ & -.381 & -.116 \\
\hline
\end{tabular}

***** ve ${ }^{*}$ sirasıyla \%1, \%5 ve \%10 istatistiksel önem seviyesini ifade etmektedir.

Logit modellerinde, bağımsız değişkenlerin 1 birim artırılmasıyla (diğer değişkenler sabit tutulur) bu değişimin bağımlı değişkenin gerçekleşme olasılığında nasıl bir etki oluşturacağını göstermek için değişkenlere ait marjinal etkilere bakılabilir.

- Sağlığından memnun olan bireylerin sağlığından memnun olmayan bireylere göre yaşamdan memnun olma olasılığı \%47,6 daha azdır. (Referans: memnun değil)

- Sağlığından orta derece memnun olan bireylerin sağllğından memnun olmayan bireylere göre yaşamdan memnun olma olasılığ $\% 28,6$ daha azdır. (Referans: memnun değil)

- Şimdiye kadar almış olduğunuz eğitimden memnun olan bireylerin memnun olmayan bireylere göre yaşam memnuniyeti olasılı̆̆ $\% 8,1$ daha azdır. (Referans: memnun değil)

- Aylik hanehalkı gelirinden memnun olan bireylerin memnun olmayan bireylere göre yaşam memnuniyeti olasılığ $1 \%$ 34,6 daha azdır. (Referans: memnun değil)

- Aylık hanehalkı gelirinden orta derece memnun olan bireylerin memnun olmayan bireylere göre yaşam memnuniyeti olasılığ $1 \% 21$ daha azdır. (Referans: memnun değil)

- Sosyal hayatından memnun olan bireylerin memnun olmayan bireylere göre yaşam memnuniyeti olasıllğ $1 \%$ 23,5 daha azdır. (Referans: memnun değil)

- Sosyal hayatından orta derece memnun olan bireylerin memnun olmayan bireylere göre yaşam memnuniyeti olasılığı \% 18,6 daha azdır. (Referans: memnun değil) 
- Akraba ilişkilerinden memnun olan bireylerin memnun olmayan bireylere göre yaşam memnuniyeti olasılığ $\% 43,4$ daha azdır. (Referans: memnun değil)

- Akraba ilişkilerinden orta derece memnun olan bireylerin memnun olmayan bireylere göre yaşam memnuniyeti olasılığ $\% 35,9$ daha azdır. (Referans: memnun değil)

- Asayiş hizmetlerinden memnun olan bireylerin memnun olmayan bireylere göre yaşam memnuniyeti olasılığ \% 17,6 daha azdır. (Referans: memnun değil)

- Asayiş hizmetlerinden orta derece memnun olan bireylerin memnun olmayan bireylere göre yaşam memnuniyeti olasılığ $\% 18,8$ daha azdır. (Referans: memnun değil)

- Ulaştırma hizmetlerinden memnun olan bireylerin memnun olmayan bireylere göre yaşam memnuniyeti olasılığı \%9,7 daha fazladır. (Referans: memnun değil)

- Son bir hafta içinde ücretli ya da ücretsiz olarak bir işte çalışmayan ancak işi ile ilgisi devam eden bireylerin çalışmayan bireylere göre yaşam memnuniyeti olasılığ $\% 26,8$ daha fazladır. (Referans: çalışmadı)

- Kendisine ayırdığı zamandan memnun olan bireylerin memnun olmayan bireylere göre yaşam memnuniyeti olasılığ $1 \% 14,1$ daha azdır. (Referans: memnun değil)

- Evli bireylerin eşi ölmüş bireylere göre yaşam memnuniyeti olasılığı \%24,9 daha azdır. (Referans: eşi öldü)

\section{Sonuç}

İnsanlık tarihinde gerek ekonomik kalkınma açısından gerekse refah bakımından önem arz eden yaşam memnuniyeti kavramı ulusal ve uluslararası yazında çok farklı yönleriyle ele alınmakta ve üzerinde çalışmalar yürütülmektedir. Bu bakımdan Kayseri ilinde bulunan bireylerin yaşam memnuniyetlerini etkileyen faktörleri belirlemeye yönelik araştırmamızda da TÜIK tarafından 2013 yılında gerçekleştirilmiş Yaşam Memnuniyeti anket verilerinden yararlanılmıştır. Bu doğrultuda bağımlı ve bağımsız değişkenler belirlenmiş ve bireylerin yaşam memnuniyeti üzerinde etkisi olduğu düşünülen değişkenlerin tespit edilmesi için Sıralı lojistik regresyon yönteminden yararlanılmıştır. Kurulan modelin öncelikle paralel eğriler varsayımını sağlayıp 
sağlamadığı test edilmiştir. Bu varsayımın kontrolü için Wald Testi kullanılmış olup sonuç olarak sıfır hipotezinin kabul edildiği ve bu sayede paralel eğriler varsayımını sağladığı tespit edilmiştir. Model, uyum iyiliği testlerine tabi tutulduğunda da model uyum iyiliği testlerinin de karşılandığı belirlenmiştir. Bir sonraki aşamada ise yaşam memnuniyetinin bağımlı değişken olarak belirlendiği çalışmada istatistiksel olarak anlamlı bulunan bağımsız değişkenler ile sıralı logit modele ait sonuçların Odds oranı değerleri vasıtasıyla değerlendirilmesi yoluna gidilmiştir. Son olarak marjinal etkiler hesaplanmış olup yorumlanmıştır. Araştırma sonucunda bireylerin yaşam memnuniyetini etkileyen faktörlerin; sağlık, eğitim, gelir, sosyal hayat, akraba ilişkileri, çalışma durumu, kişisel durum, medeni durum, ulaşım hizmetleri, asayiş hizmetleri ve okul bitirme durumu olduğu tespit edilmiştir. Elde edilen çalışma bulguları literatürde yapılmış birçok çalışmanın sonucu ile benzerlik göstermektedir. Graham ve Pettinato (2001), çalışmalarında eğitim seviyelerinin yaşam memnuniyeti üzerinde anlamlı etkilere sahip olduğunu test etmiştir. Peiro (2006) 15 ülkede bireylerin mutluluk ve sosyo-ekonomik koşullarını araştırdığı çalışmada sağlık, medeni durum ve mutluluk arasında bir ilişki olduğu sonucuna ulaşmıştır. Dumludağ, Gökdemir ve Giray (2016) 2011 yılı yaşam memnuniyeti verilerini kullanarak gelir ve evlilikle, mutluluk arasındaki pozitif ilişkinin varlığına dikkat çekmişlerdir. Borooah (2006) yaptığı çalışmada 80 ülkeden alınan yaklaşık 113.000 katılımcıya ait verileri kullanarak gerçekleştirdiği çalışmasında insanların mutlu olmak için genellikle aynı şeyleri istediğini tespit etmiştir. Bunlar, Tanrıya inanma, insanca bir yaşam standardı, bir iş, iyi bir aile ve sosyal hayat, iyi komşuluk ve en önemlisi sağlıklı olma istekleridir. Batı ve Orta Avrupa'daki 8 ülkede yaşam memnuniyeti üzerinde belirleyici olan faktörleri çoklu regresyon modeli yardımıyla inceleyen bir çalışma sonucunda Asandului ve Hritcu (2012), kişisel ilişkiler ve yüksek statünün yaşam memnuniyetini olumlu yönde etkilediği sonucuna ulaşmışlardır (Korkmaz, vd., 2015).

Gelecek çalışmalarda faklı analiz yöntemleri ile yaşam memnuniyetine ilişkin değerlendirmeler yapılabilir ve daha fazla il ve gösterge dikkate alınarak yaşam kalitesinin artırılmasına yönelik çözüm önerilerinde bulunulması önerilebilir. 
EXTENDED ABSTRACT

\title{
The Research of Factors That Affects on Life Satisfaction: The Sample of Kayseri Province
}

\author{
Hakan Eygü - Arife Kılınç \\ Atatürk University
}

Without exception, interpersonel trust rates are higher in countries with high life satisfation. Interpersonel trust, which is the main element of social capital, is an expression of our beliefe in people we did not know and had no idea about. While this beliefe significantly explains economic success as an indicator of individuals' willingness to cooperate, it is also one of most important social determinants of life satisfaction. Because socia-demographic and economic factors obtain importance in evaluating individual life satisfaction. In essence, life satisfaction is a subjective assessment of the quality of one's life. Beceuse it is inherently an evaluation, judgments of life satisfation have a large cognitive component.

There is a direct proportion between satisfaction with one's life and quality of life. Because high life satisfaction indicates that the quality of life level in societies is good. Likewise, low life satisfaction indicates some important deficiencies in the quality of life level. Therefore, high life satisfaction is a situation people want to achieve. It is possible to mention many criteria that are thought to affect the life satisfaction of the person. Diener (1984), Judgments of satisfaction are de- pendent upon a comparison of one's circumstances with what is thought to be an appropriate standard. It is important to point out that the judgment of how satisfied people are with their present state of affairs is based on a comparison with a standard which each individual sets for him or herself; it is not externally imposed. It is a hallmark of the subjective well-being area that it centers on the person's own judgments, not upon some criterion which is jpdged to be important by the researcher. Margolis et al. (2019) also indicated that most studies seem to be targeting overall life satisfaction rather than particular domain satisfactions. Accordingly, a measure with items that assess overall life satisfaction is desirable for two reasons. 
First, measuring domain satisfaction involves a trade-off between comprehensiveness and efficiency.

When the dependent variable (accident severity) is discrete andcontains more than two categories, the multinomial logistic regression(logit) model is a well-established method to use (Khorashadi, Niemeier, Shankar and Mannering, 2005). The multinomial logit modelcombines the independent variables to estimate the probability that aparticular event will occur; in this case the probability of an accidentto be slight, serious, or fatal. When the order of the values is takeninto consideration, thus hierarchy has a natural meaning such as inthis study, the commonly used model is an ordered logistic regression (Ouddus, Wang and Ison, 2010).

Regression methods have an important place in statistics. Regression analyzes take an important place in investigating the effects of the determined independent variables on the dependent variable and determining the relationship between these variables. It is possible to apply linear, logit, probit and ordered logistic regression techniques if the assumptions of dependent variables and models are provided. Dependent variables can be continuous or can be measured as two-state or ordered multi-state. A logistic regression model tryin to use independent variables to predict, what is the likely response of each individual in the survey is ordinal logistic regression. In some sense the situation is intermediate between regression and classification. The model onl applies to data that meet the proportional odds assuption. In this study is to research the influence of various factors that affects the life satisfaction of individuals living in Kayseri province. For this purpose, data the 2013-Life Satisfaction Survey, which the applied to 2786 people living in Kayseri province of Turkish Statistical Institute were used in the study. It was determined that it is appropriate to use Ordered Logistic Regression model for the obtained data.

\section{Kaynakça / References}

Ahn, N. Garcia, J. R. ve Jimeno, J. F. (2004). The impact of unemployment on individual well-being in the EU. Europen Network of Economic Policy Research Institutes, Working paper, No:29.

Ağbektaş, A. (2016). Yaşam memnuniyeti araştırmasında istatistiksel tekniklerin kullanulması Sivas Il örneği. Yüksek Lisans Tezi. Sivas: Cumhuriyet Üniversitesi Sosyal Bilimler Enstitüsü İşletme Anabilim Dalı Sayısal Yöntemler Bilim Dalı. 
Akın, H. B. ve Şentürk, E. (2012). Bireylerin mutluluk düzeylerinin ordinal lojistik regresyon analizi ile incelenmesi. Öneri Dergisi, 10(37), 183-193.

Aktaş, A.R., Özkan, B. ve Oku, O. (2012). Analysis of factors affecting the life satisfaction of household heads living in urban areas; A Case Of West Mediterranean Region. Conference: 3rd International Symposium on Sustainable Development, Saraybosna, Bosna-Hersek.189-198

Aslangiray, A. (2016). Yaşam memnuniyetini etkileyen faktörlerin modellenmesi: Batı Akdeniz örneği. Doktora Tezi. Antalya: Akdeniz Üniversitesi Sosyal Bilimler Enstitüsü İşletme Ana Bilim Dalı.

Borooah, V. K. (2006). How much happiness is there in the world? A cross-country study. Applied Economics Letters, 13(8), 483-488.

Bülbül, Ş. ve Giray, S. (2012). İş ve özel yaşam (iş dışı yaşam) memnuniyeti arasındaki ilişki yapısının doğrusal olmayan kanonik korelâsyon analizi ile incelenmesi. Anadolu Üniversitesi Sosyal Bilimler Dergisi, 12(4), 101-114.

Chen, C.K. ve Hughes, J. (2004). Using ordinal regression model to analyze student satisfaction questionnaires. Association for Institutional Research, 1, 1-13.

Demircan, S. (2015). TÜİK yaşam memnuniyeti anketleri üzerine veri madenciliği uygulaması. Yüksek Lisans Tezi. Kayseri: Erciyes Üniversitesi Fen Bilimleri Enstitüsü Endüstri Mühendisliği Anabilim Dalı.

Demirtas, E.A., Anagun, A.S. ve Koksal, G. (2009). Determination of optimal product styles by ordinal logistic regression versus conjoint analysis for kitchen faucets. International Journal of Industrial Ergonomics, 39(5), 866-875.

Diener, E. (1984). Subjective well-being. Psychological Bulletin, 95, 542-575.

Diener, E. D., Emmons, R. A., Larsen, R. J. ve Griffin, S. (1985). The satisfaction with life scale. Journal of Personality Assessment, 49(1), 71-157.

Dumludağ, D. Gökdemir, Ö. ve Giray, S. (2016) Income comparison, collectivism and life satisfaction in Turkey. Quality $\mathcal{E}$ Quantity. 50, 955-980.

Eygü, H. ve Güllüce, A.Ç. (2017). Determination of customer satisfaction in conservative concept hotels by ordinal logistic regression analysis. Journal of Financial Risk Management, 6, 269-284.

Frank, E. ve Harrell, J. (2001). Regression modeling strategies, with applications to linear models, logistic regression and survival analysis.Springer Series in Statistics, 568.

Giray, S. (2011). Doğrusal olmayan kanonik korelasyon analizi ve yaşam memnuniyeti üzerine bir uygulama. Doktora Tezi. İstanbul: Marmara Üniversitesi Sosyal Bilimler Enstitüsü Ekonometri Anabilim Dalı İstatistik Bilim Dalı. 
Graham, C. L. ve Pettinato, S. (2002).Frustrated achievers: winners, losers and subjective well-being in new market economies. Journal of Development Studies, 38(4), 100-140.

Gürsakal, S. ve Öngen, K.B. (2008). 2007 Yaşam memnuniyeti anketinin istatistiksel yöntemler ile analizi. Uludağ Üniversitesi İktisadive İdari Bilimler Fakültesi Dergisi, 27(1), 1-14.

Işı̆̆ıçok, E. (2003). Bebeklerin doğum ağırlıkların ve boylarını etkileyen faktörlerin lojistik regresyon analizi ile karşlaş̧trılması. IV. Ulusal Ekonometri ve İstatistik Seтроzyumu, Gazi Üniversitesi, Ankara.

Kahyaoğlu, O. (2008). Yaşam memnuniyeti ve yaşam memnuniyetini etkileyen değişkenler ile ekonometrik uygulama: Türkiye örneği. Yüksek Lisans Tezi. İzmir: Dokuz Eylül Üniversitesi Sosyal Bilimler Enstitüsü Ekonometri Anabilim Dalı.

Kalayc, Ş. (2010). SPSS uygulamalı çok değişkenli istatistik teknikleri. 5. Baskı, Ankara: Asil Yayın.

Kangal, A.(2013). Mutluluk üzerine kavramsal bir değerlendirme ve Türk hanehalkı için bazı sonuçlar. Electronic Journal of Social Sciences, 12(44), 214-233.

Kapteyn, A., Smith, James P. ve van Soest, A. (2009). “Life Satisfaction”, Discussion Papers, No. 4015, IZA (The Institute for the Study of Labor), Germany

Kartal, S. E., Yirci, R. ve Özdemir, T.Y. (2015). Öğretmenlerde algilanan örgütsel destek düzeyi ile yaşam memnuniyeti arasındaki ilişkinin incelenmesi. Dicle Üniversitesi Ziya Gökalp Eğitim Fakültesi Dergisi. 24, 477-504.

Khorashadi, A., Niemeier, D., Shankar, V., \& Mannering, F. (2005). Differences in rural and urban driver-injury severities in accidents involving large-trucks: an exploratory analysis. Accident Analysis \& Prevention, 37(5), 910-921.

Korkmaz, M., Germir, H.N., Yücel, A.S. ve Gürkan, A. (2015). Yaşam memnuniyeti üzerinde etkili olan sosyo-demografik bileşenler üzerine bir analiz. Uluslararası Hakemli Psikiyatri ve Psikoloji Araştırmalan Dergisi, 3(2), 78-111.

Kutlar, A., Işık, T. T. ve Torun, P. (2013). Kadının yaşam memnuniyetini belirleyen faktörler: Adıyaman, Isparta, Kocaeli örneği. Cumhuriyet Üniversitesi İktisadi ve İdari Bilimler Dergisi, 14(2), 145-159.

Margolis, S., Schwitzgebel, E., Ozer, D. J., \& Lyubomirsky, S. (2019). A new measure of life satisfaction: The Riverside Life Satisfaction Scale. Journal of personality assessment, 101(6), 621-630.

O'Connell, Ann, A. (2006). Logistic regression models for ordinal response variables. Quatitative Applications in the Social Sciences, Sage Publications, 105. 
Olena K., (2005), Analysis of life satisfaction in Ukraine. Published Master Thesis, Economics Education and Research Consortium Master"s Program in Economics, Ukraine.

Orçanll, K., Oktay, E. ve Birgören, B. (2018). Kış sporları merkezlerine farkındalık algısının oluşmasını etkileyen faktörlerin belirlenmesi (Erzurum Illi örneği). Sosyal Bilimler Araştirma Dergisi, 7(3), 1-19.

Peiro, A. (2006) Happiness, satisfaction and socio-economic conditions: some international evidence. The Journal of Economics, 35, 348-365.

Quddus, M. A., Wang, C., \& Ison, S. G. (2010). Road traffic congestion and crash severity: econometric analysis using ordered response models. Journal of Transportation Engineering, 136(5), 424-435.

Servet, O. (2017). Mutluluğun Türkiye'deki belirleyenlerinin zaman içinde değişimi. Akdeniz I.I.I.B.F. Dergisi, 35, 16-42.

Sümbüloğlu, K. ve Akdağ, B. (2007). Regresyon yöntemleri ve korelasyon analizi. Ankara: Hatipoğlu Yayınları.

Şehribanoğlu, S. ve Diler, S. (2018). 2013 yılı yaşam memnuniyeti araştırmasının c\&rt ve chard algoritmaları ile incelenmesi. Akademik Sosyal Araştrmalar Dergisi, 6(67), 132-141.

Şerbetçi, A. (2012). Stralı lojistik regresyon analizi ile istatistik ve ekonometri derslerinde başaruy etkileyen faktörlerin belirlenmesi: Atatürk Üniversitesi iktisadive idaribilimler fakültesi öğrencileri üzerine bir uygulama. Yayınlanmış Yüksek Lisans Tezi. Erzurum: Atatürk Üniversitesi Sosyal Bilimler Enstitüsü.

Şerbetçi, A. ve Özçomak, M.S. (2013). Sıralı lojistik regresyon analizi ile istatistik ve ekonometri derslerinde başarıyı etkileyen faktörlerin belirlenmesi: Atatürk üniversitesi iktisadi ve idari bilimler fakültesi öğrencileri üzerine bir uygulama. Kahramanmaraş Sütçü İmam Üniversitesi İktisadi ve İdari Bilimler Fakültesi Dergisi, $3(1), 89-110$.

тÜіK,(2015). тய̈їK Haber Bülteni, Yaşam Memnuniyet Araştrması. http://www.tuik.gov.tr/PreHaberBultenleri.do?id=18629. Adresinden erişilmiştir.

Timur, B. ve Akay, E. Ç. (2017). Kadın ve erkeklerin mutluluğunu etkileyen faktörlerin genelleştirilmiş sıralı logit modeli ile analizi. Sosyal Bilimler Araştırma Dergisi, 6(3), 88-105. 


\section{Kaynakça Bilgisi / Citation Information}

Eygü, H. ve Kılınç, A. (2020). Yaşam memnuniyeti üzerinde etkili olan faktörlerin araştırılması: Kayseri İli örneği. OPUS-Uluslararası Toplum Araştırmaları Dergisi, 16(Özel Say1), 3591-3618. DOI: 10.26466/opus.791217 